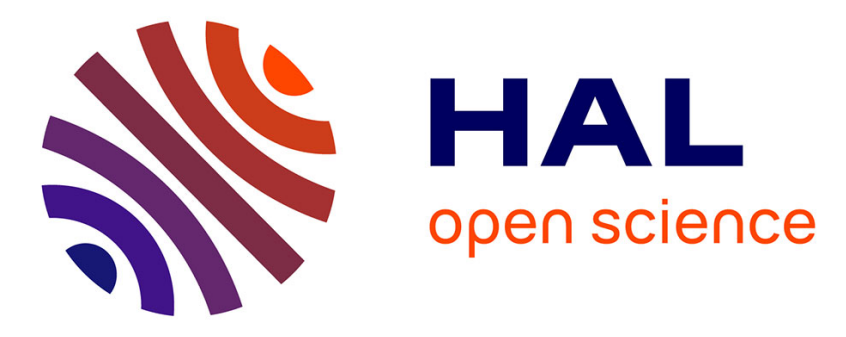

\title{
Life Cycle Assessment Electricity Generation from Landfill in São Paulo City
}

Marise De Gomes, José Benedito Sacomano, Fabio Papalardo, Alexandre Da Silva

\section{- To cite this version:}

Marise De Gomes, José Benedito Sacomano, Fabio Papalardo, Alexandre Da Silva. Life Cycle Assessment Electricity Generation from Landfill in São Paulo City. IFIP International Conference on Advances in Production Management Systems (APMS), Sep 2015, Tokyo, Japan. pp.632-639, 10.1007/978-3-319-22756-6_77 . hal-01417627

\section{HAL Id: hal-01417627 \\ https://hal.science/hal-01417627}

Submitted on 15 Dec 2016

HAL is a multi-disciplinary open access archive for the deposit and dissemination of scientific research documents, whether they are published or not. The documents may come from teaching and research institutions in France or abroad, or from public or private research centers.
L'archive ouverte pluridisciplinaire HAL, est destinée au dépôt et à la diffusion de documents scientifiques de niveau recherche, publiés ou non, émanant des établissements d'enseignement et de recherche français ou étrangers, des laboratoires publics ou privés.

\section{(c)(1)}

Distributed under a Creative Commons Attribution| 4.0 International License 


\title{
Life Cycle Assessment electricity generation from landfill in São Paulo City
}

\author{
Marise de Barros Miranda Gomes ${ }^{1,2}$, José Benedito Sacomano ${ }^{1}$, Fabio Papalardo ${ }^{1}$, \\ Alexandre Erdmann da Silva ${ }^{2}$ \\ ${ }^{1}$ Universidade Paulista (UNIP), Post Graduate Program in Production Engineering, Dr. \\ Bacelar St. 1212, São Paulo, Brazil \\ ${ }^{2}$ Centro Universitário das Faculdades Metropolitanas Unidas - FMU, São Paulo, São \\ Paulo. \\ \{marise.gomes@superig.com.br\}
}

\begin{abstract}
A municipal solid waste landfills are complex systems, because your waste in a landfill body has a large heterogeneous mixture, high levels of different organic and inorganic matter. Environmental problems are results about intense urbanization, but different solutions offered for alternatives mitigating the environmental_impacts. These solutions are the best practices in the recovery of such wastes when disposed of in landfills. But recent concepts in modern landfill management, in the São Paulo City, incorporate strategies in their life cycle, so since the beginning of the landfill, different techniques have been tested to stabilize the amount of methane gas emissions and energy recovery. This work finds the perspective, sustainability electricity generation, these uses of landfill gas are divided into electricity generation and direct use. The scenery, study sustainability indicators are Bandeirantes Landfill, with application of fuzzy logic to estimate production methane for energy generation.
\end{abstract}

Keywords. Landfill, fuzzy logic, sustainability, recovers energy, renewable energy.

\section{$1 \quad$ Introduction}

Recent concepts in modern landfill management, incorporate sustainability indicators in their life cycle, when the beginning of the landfill, many techniques are tested to stabilize the amount of methane gas emissions, included estimations using linear and no-linear models [1]. Energy recovery is one of the indicators of sustainability for landfills, but these systems necessitates estimation of gas released and its energy potential, [2].

Sustainability, it's a term created by the Helmholtz Institute [3], an important center of research and technology from Germany, highlights the use of energy and natural resources in an efficient, safe and sustainable way. Therefore, it defines the minimum requirements that are universally valid for the global sustainable development, unconventionally. It assigns the deficit of sustainability indicator to the forecasts of global energy shortage, to 
power supply or generation, to the extraction of raw materials and waste disposal without its energy recovery.

This methodological approach is based on the integrative sustainability concept developed by the Helmholtz Association. Its large idea is that the abstract notion of sustainability has to be adapted to a specific local situation, in this case, Bandeirantes Landfill, in order to make its meaning clear. Therefore, it defines the minimum requirements that are universally valid for the global sustainable development, unconventionally. It assigns the deficit of sustainability indicator to the forecasts of global energy shortage, to power supply or generation, to the extraction of raw materials and waste disposal without its energy recovery.

Landfills operating and maintenance costs are expensive for Brazilian municipalities, resolution 404 of the National Environmental Council and the law 11.107/2005, complementary to each other, assist in retrenchment strategies by the landfill sharing between municipalities in the same region [4;5]. The first one establishes a set of guidelines to obtain environmental licensing for small landfills, and the second one sets norms for the management in intermunicipal consortium [6].

It is estimated that Brazil has 1,723 landfills, [7]. The soil is prepared so that garbage does not affect the environment, does not cause bad odors, and does not contribute to visual pollution or to the proliferation of animals. When the waste decomposes it generates leachate: a pollutant liquid, methane gas, and other pollutants. Methane causes pollution and it is about 20 times worse for the Earth's climate than carbon dioxide emissions.

The motivation of this study reinforces that the technical parameters adopted to determine the energy potential of this type of enterprise have been developed to landfills in other countries. Therefore, design features, its operation, waste types and climatic conditions are different in the national landfills, endangering the sustainability of the landfill as an alternative energy source.

\subsection{A review the life cycle Bandeirantes and parameters reference}

From 2008, the Bandeirantes landfill began to operate as an independent producer and supplier of electricity. The expectation of this last phase is estimated to expire in 2030. The highest peak of sustainable production and methane generation was recorded in 2004, when it was still operating as a landfill.

Estimate the total amount of methane gas produced in landfills, variables such as time and phases of waste decomposition should be considered. Besides these influencing factors, the degradation process influences the potential to generate methane gas, which can reach about $400 \mathrm{~m} 3 /$ ton of dry residue, [8].

Indeed, was presented the results of a study conducted in 20 landfills in northern Germany, [9]. The variations in the generation of methane depend on landfill soil compaction, on rainfall, and on the concentration of each type of material in different points. The climatic conditions of each region analyzed, as well as the operation of landfills, are also factors that influence the quality and quantity of production of methane gas. Finally, the research by this author also considered the amount of oxygen penetrating into the soil, the $t$ soil type and its granularity and distribution of the amount of water in various parts of the landfill. Soil type and its granularity and distribution of the amount of water in various parts of the landfill.

Many procedures and methodologies evaluated two methods for the estimation landfill gas sustainability, [10]. One of them is called design method of IPCC [11] and the method 
of first-order decay known as the equation of USEPA [12]. The authors recommend further research on different methods, but concluded that the design method estimates lower rates of methane generation, since it takes into account the

\section{Methodology}

\subsection{Study theoretical about Emission Factor and Collection Factor}

The first equations of calculation methods for estimating methane generation did not consider the emissions, part of which migrated to the atmosphere and others were absorbed and degraded in the surface layers of the territorial plan of the landfill, among many other parameters. According to the IPCC [11], different methods and mathematical models were used to estimate the emissions in landfills. This variability did not allow the application in regions or even in countries, due to the heterogeneity of climate, soil, rainfall, among other factors.

It was conducted in a study on the application of the mathematical model in different CDM projects in developing countries, comparing with the measured results, [13]. The countries involved in the study were Brazil, China, Argentina and Chile. The author's conclusion was that the models refer to different optimal precisions of the actual measurements and cannot adequately explain the composition of the wastes and the site conditions which are different from the landfills in developed countries.

Research also emphasizes that the initial model evolved in order to improve accuracy because of the variables that affect the chemical reactions, [14]. They indicate constraints on the models such as the complexity of gas generation, depending on several variables, according to the particular conditions of each landfill, such as soil, moisture, and climate.

Thus, in order to calculate the methane generation in this study, we used the eq1 equation, as follows.

Where:

$$
\mathbf{Q C H}_{\mathbf{C}}=\mathbf{L} 0 * \mathbf{R} *(\mathbf{e}-\mathrm{kc}-\mathbf{e}-\mathrm{kt})
$$

$Q_{C H 4}=$ Methane generated in year $\mathrm{t}\left(\mathrm{m}^{3} /\right.$ year $)$;

$L 0=$ Potential of methane generation $\left(\mathrm{m}^{3} /\right.$ ton);

$R=$ Annual average of garbage input at the dump, (ton / year);

$K=$ Methane generation rate $=0.04$ (half life from 4 to 2 years);

$c=$ year since the closure;

$t=$ year since the beginning of the activity (year).

It is noteworthy that, in the [eq1] equation, the variables $\mathrm{c}$ and $\mathrm{t}$ are equivalent to the variables $t$ and $y$ respectively presented in [eq1] equation. In [eq1], there is the representation of the sum $(\Sigma)$ of all years for the decay variable. There is also a technical motivation for adopting another tool instead of the one proposed by USEPA [12].

The first-order equation, [eq1], has the period of 1 year as time, and not the time in its lower part, for example, the production of gas in each second of time. Making projections of gas production at all time points would be limited, even if finitely. Only supercomputers 
could perform some processing on this level of accuracy, adding the projections of the landfill gas lifecycle of 20,30, 40 or more years ahead.

The potential methane generation capacity, or $\mathrm{L}_{0}$, describe the total amount of methane gas potentially produced by a metric ton of waste as it decays. EPA determined that the appropriate values for L0 range from 56.6 to $198.2 \mathrm{~m} 3$ per metric ton or megagram (m3 $/ \mathrm{Mg}$ ) of waste, in practice. Except in dry climates where lack of moisture can limit methane generation, the value for the $\mathrm{L}_{0}$ depends almost entirely on the type of waste present in the landfill. The higher the organic content of the waste, the higher the value of $\mathrm{L}_{0}$, this is a sustainability factor. Note that the dry organic content of the waste determines the L 0 value, and not the wet weight measured and recorded at landfill scale houses, as water does not generate LFG. Some tools have a refers sets $\mathrm{L}_{0}$ to a default value of $170 \mathrm{~m} 3 / \mathrm{Mg}$ to represent a conventional landfill.

Abrelpe [15] highlights the difficulty of finding the database in order to estimate accurately the values of L0 and $\mathrm{k}$. It recommends the adoption of the rating factor of the waste disposal site, table [1]. This factor is associated with L0 variable and it influences the potential of methane gas generation.

\begin{tabular}{|c|c|}
\hline Site & Emission Factor (EF) \\
\hline Landfill & 1.0 \\
\hline Controlled landfill & 0.8 \\
\hline Trash dump & 0.4 \\
\hline
\end{tabular}

Table [1] - Emission Factor - EF

This emission factor associated with the site of residue destination interferes with the estimated portion of generation of methane gas. Landfills have factor 1 of $100 \%$. It is estimated that these sites have adequate control regarding the handling and compaction of waste [16].

The table [2] presents the simulation results of the matrix that combines the emission factor and the collection factor with three types of disposal sites, according to the [eq3] equation, named for this calculation as $\mathrm{L}^{\prime}=[\mathrm{EF}] *[\mathrm{CEF}]$.

\begin{tabular}{|c|c|c|}
\hline Site category & $\mathrm{EF}=0.6$ & $\mathrm{CEF}=0.85$ \\
\hline 1 & 0.6 & 0.85 \\
\hline 2 & 0.48 & 0.68 \\
\hline 3 & 0.24 & 0.51 \\
\hline
\end{tabular}

Table [2] - Simulation result for $\mathrm{L}_{0}{ }^{\prime}\left(\mathrm{m}^{3} / \mathrm{ton}\right)$

In the simulation shown in table 2, the three categories were divided into 1 for landfill, 2 for controlling landfill and 3 to trash dump. The last one had the lowest result regarding the Lo' variable. The blue column was coded for the results of $60 \%$ collection percentage and the red column to $85 \%$ performed collection.

The results emphasize that the collection factor affects the emission factor, the lower the collection factor the lower the potential for methane gas production. When the collection 
factor tends to increase, the potential for methane generation tends positively too. Although the collection factor is the same for landfills and controlled landfills, the numbers remained different in the two cases (EF and CEF).

\subsection{Application of Fuzzy Logic Model for estimating the production of methane gas in landfill}

Fuzzy logic is widely used in a machine control, for example. The term fuzzy refers to the logic involved can deal with concepts that cannot be expressed as the "true" or "false" but rather as "partially true".

This paper presents fundamental ways an existing model for the numerical assessment of sustainability called sustainability assessment by fuzzy evaluation.

About the uncertainties of solid waste characteristics, as well as the complex physical, chemical, and biological processes taking place within the Bandeirantes landfill, motivated advanced modeling techniques to be applied; mathematical modeling and fuzzy logic systems [17].

\section{$3 \quad$ Results and Discussion}

\subsection{Simulation Potential Emissions from energy recover}

In this modeling of the sustainable production of electricity, the Bandeirantes landfill is named as Thermal Power Plant. The tests represent three scenarios,

In the simulation shown in chart following, the three categories were divided into 1 for landfill, 2 for controlling landfill and 3 to trash dump. The last one had the lowest result regarding the Potential of methane generation variable, fig [1].

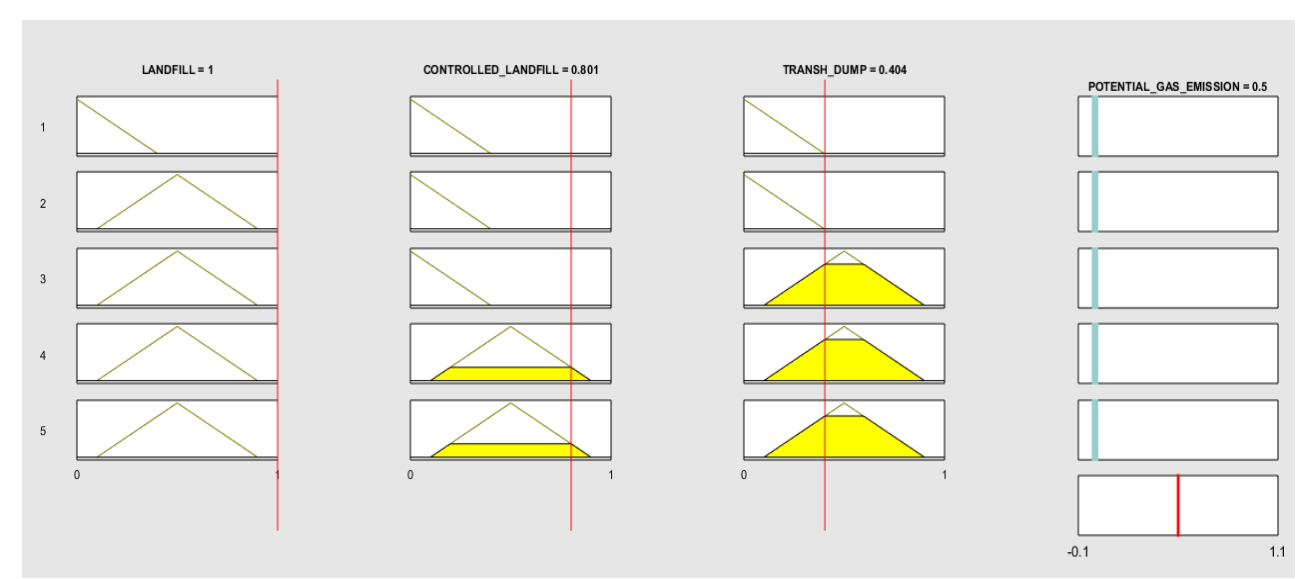

Fig [1] - Simulation result for $\mathrm{L}_{0}\left(\mathrm{~m}^{3} /\right.$ ton$)$ with Simulink Fuzzy 
The fig [1] Simulink Fuzzy was coded for the results of $60 \%$ collection percentage for trash dump and the to $85 \%$ performed collection decrease for controlling landfill. The potential of methane generation had the following results in the simulation compiled.

See fig [1], the first fuzzy logic when landfill, it is not possible. The simulation of this scenario shows, in fig [1], that there was an improvement in the performance of methane gas generated in all sites of waste disposal, even more at the trash dump. The simulation of this scenario shows, in fig [1], that there was an improvement in the performance of methane gas generated in all sites of waste disposal, even more at the dump. The two locations of inappropriate disposal had their emissions increased.

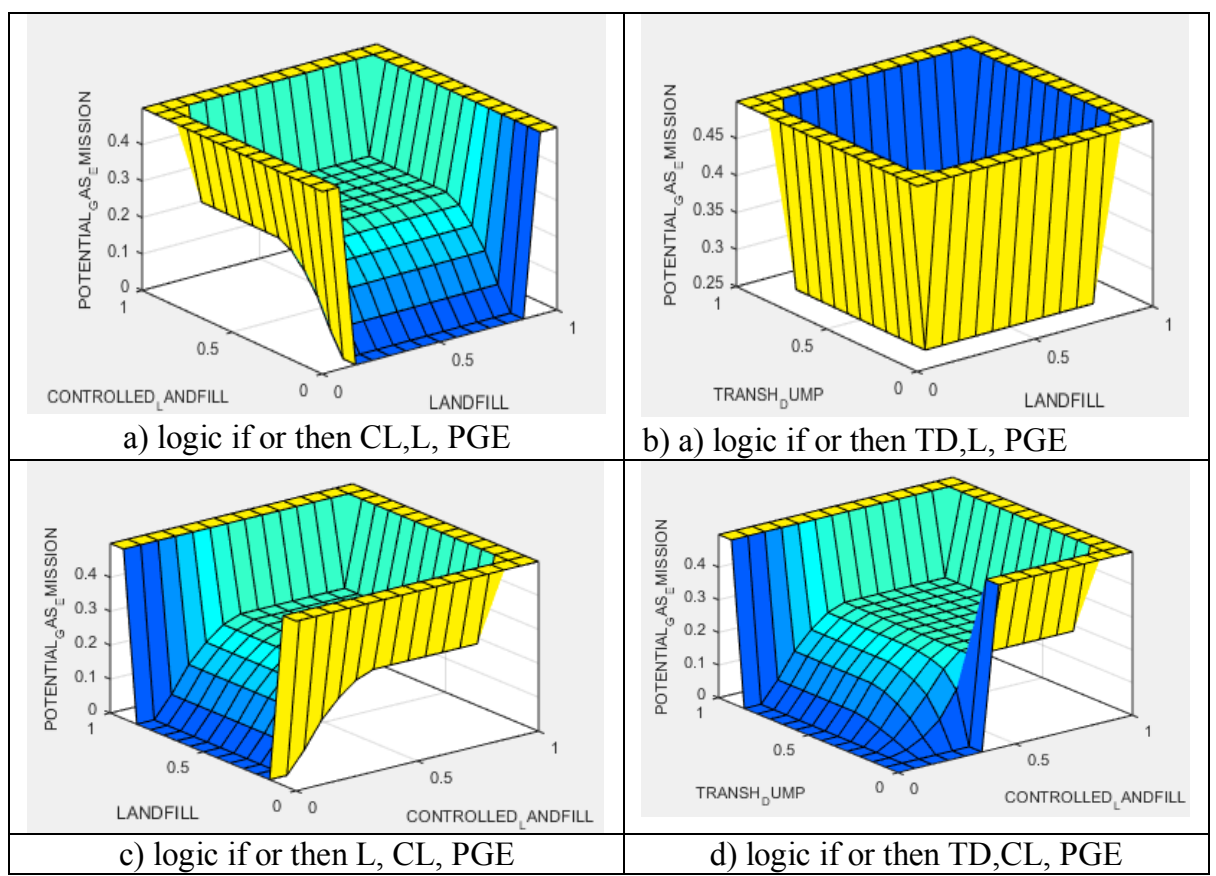

Fig [2] - Simulation surface result for $\mathrm{L}_{0}\left(\mathrm{~m}^{3} /\right.$ ton $)$ - L ( Landfill); TD (trash dump); CL (controlled landfill); PGE ( Potential gas emission)

The simulation was repeated, by changing the vector order of the matrix elements. The result was exactly the same, proving that the result of the first simulation was correct, thus confirming the increase in methane generation in plants considered inadequate, but with the amount of gas production that is not used.

The performance in humid and dry climates improves gas production and affects it in semi-humid climate, according to the result of fig [2]. Although it has adopted the worst values for methane production, the performance to landfill is better in the " $b$ " case when compared with the "d" case. But case simulation "a" and "c", haven't good potential emissions.

The humid and dry climates positively affect the production of gas in the controlled landfill, staying above the result influenced by semi-humid climate in the landfill. 
In $4^{\text {nd }}$ case, the results show a balanced performance. The semi-humid climate improves gas production in the landfill staying above the gas production in controlled landfill and landfill influenced by the three climates. The current Bandeirantes Thermal Power Plant was initially a trash dump, evolving to a controlled landfill and then to landfill, which was closed in 2006. This three-stage production cycle generated a volume of methane gas with potential for energy recovery.

\section{Conclusions}

They work with fuzzy logic in the future when the project goes into operation as a plant, and they do not consider the methane potential in the production cycle, discarding energy production since the establishment of the plant. In this scenario, the plant did not value $50 \%$; this corresponds to the production of 2,356,207 MWh. It would be possible to fuel the plant and still have 2,244,175 MWh.

This simulation doesn't show that by 2030 , the plant will produce $1,424,148,778$ $\mathrm{m}^{3}$ of GHG (greenhouse gas). The potential emission for recovering energy it's a good performance when increase disposal trash.

The number of controlled landfills, trash dumps and landfills that are not recovering the methane as energy and carbon credits deserves to be evaluated. Producing energy and, on the other hand, trading carbon credits on the market as a commodity of energy production can be a good investment. The issue of controlled landfills, landfills or trash dumps undergo a recent great transformation.

The fuzzy logic application in this test refines and extends tool for the numerical assessment of sustainability.

References

1. Yacovitch, T. L.; Herndon, S. C.; Pétron, G.; Kofler, J.; Lyon, D.; Zahniser, M. S.; and Kolb, C. E. Mobile Laboratory Observations of Methane Emissions in the Barnett Shale Region. Environmental Science \& Technology, American Chemical Society, accepted: February 23, 2015. DOI: 10.1021/es506352j, Publication Date (Web): March 9, 2015.

2. Kumar, A.; Dand, R.; Lakshmikanthan, P., and Babu, G. L. S. Methane Production Quantification and Energy Estimation for Bangalore Municipal Solid Waste. January 2014, Volume 95, Issue1, pp 19-27.

3. Helmholtz Association of German Research Centers. Helmholtz - With Energy into the Future. Annual Report. Berlim, 2010.

4. DOU BRASIL. Presidência da República. Casa Civil. Subchefia para Assuntos Jurídicos. Lei no . 11.107, de 6 de abril de 2005. Diário Oficial da República Federativa do Brasil. Publicada no DOU de 7.4.2005.

5. CONAMA. Conselho Nacional do Meio Ambiente. Resolução Conama $n^{\circ} 404$, de 11 de novembro de 2008. Estabelece critérios e diretrizes para o licenciamento ambiental de aterro sanitário de pequeno porte de resíduos sólidos urbanos. (Publicação - Diário Oficial da União - 12/11/2008). 
6. MMA. Ministério do Meio Ambiente. Agenda 21 brasileira: resultado da consulta nacional / Comissão de Políticas de Desenvolvimento Sustentável e da Agenda 21 Nacional. 2. ed. Brasília: Ministério do Meio Ambiente, 2004, 158 p, 93.

7. MMA. Ministério do Meio Ambiente. Gestão do Lixo. Aterros Sanitários, 2010. Disponível em: $\quad<$ http://www.brasil.gov.br/sobre/meio-ambiente/gestao-do-lixo/aterros-sanitarios>. Acesso em: 31 May 2013.

8. ALVES, I. R. F. S. Análise experimental do potencial de geração de biogás em resíduos sólidos urbanos. Dissertação de Mestrado - Universidade Federal de Pernambuco. Programa de Pós-Graduação em Engenharia Civil, 2008. 118 phase, 33-34.

9. ALVES, I. R. F. S. Análise experimental do potencial de geração de biogás em resíduos sólidos urbanos. Dissertação de Mestrado - Universidade Federal de Pernambuco. Programa de Pós-Graduação em Engenharia Civil, 2008. 118 folhas, 33-34.

10. Mendes, L. G. G.; Magalhães, S. P. Estimate Methods of Biogas Generation in a sanitary landfill. Universidade Estadual Paulista - UNESP. Faculdade de Engenharia, Campus Guaratinguetá - FEG. Departamento de Energia - DEN. Rev. ciênc. exatas, Taubaté, v. 11, n. 2, p. 71-76, 2005.

11. IPCC - Intergovernmental Panel on Climate Change. Guidelines for National Greenhouse Gas Inventories. 1997. Disponível em: http://www.ipcc-nggip.iges.or.jp/public/gl/invs6.html>. Acessado em: 29 May 2012.

12. USEPA - Environmental Protection Agency. United States International Best Practices Guide for Landfill Gas energy Projects. Landfill Gas Modeling. Global Methane Initiative. Capítulo 6, 2012, 14p, pág $63-67$.

13. STEGE, G. A. Methane Emission Reductions achieved by landfill gas projects in developing countries, SCS Engineers, Phoenix, Arizona. 2009. 6 p.

14. Worrell, W. A. e Vesilind, P. A. Solid Waste Engineering. $2^{\text {a }}$ Ed, Cengage Learning, 2011. 401 p, pág 118 e 119.

15. ABRELPE. Atlas Brasileiro de emissões de GEE e Potencial Energético na Destinação de Resíduos Sólidos. Abrelpe - Associação Brasileira de Empresas de Limpeza Pública e Resíduos Especiais. Diretor Executivo: Carlos R. V. Silva Filho, 2012, 172p

16. ONU - United Nations. Sustainable Development Challenges. World Economic and Social Survey. Department of Economic and Social Affairs, UN, N. ew York, 2013. 181 p, page 68.

17. Abdallah, M.; Warith, M.; Narbaitz, R.; Petriu, E.; Kennedy, K. Combining Fuzzy Logic and Neural Networks in Modeling Landfill Gas Production. International Scholarly and Scientific Research \& Innovation. World Academy of Science, Engineering and Technology Vol:5 2011-06-25. 